\title{
Distal Enhancer Elements
}

National Cancer Institute

\section{Source}

National Cancer Institute. Distal Enhancer Elements. NCI Thesaurus. Code C13461.

Enhancer sequences found at a distance from the gene it regulates. 